\title{
Spontaneous midgut volvulus causing chylous ascites in an octogenerian
}

\author{
Steven Pengelly, ${ }^{1}$ Kali Potiszil, ${ }^{2}$ Melanie Feldman ${ }^{2}$
}

${ }^{1}$ Department of Surgery, Derriford Hospital, Plymouth, UK

${ }^{2}$ Department of Surgery, Royal Cornwall Hospital, Truro, UK

Correspondence to Steven Pengelly, steviep@doctors.org.uk

\section{DESCRIPTION}

A previously well and independent 85-year-old woman presented to A\&E with a 1-day history of sudden onset, cramping lower abdominal pain and vomiting. There were no other symptoms. The patient had a laparoscopic cholecystectomy 20 years ago but no other surgical history. On examination the patient was peripherally shutdown and abdominal examination revealed generalised peritonitis;

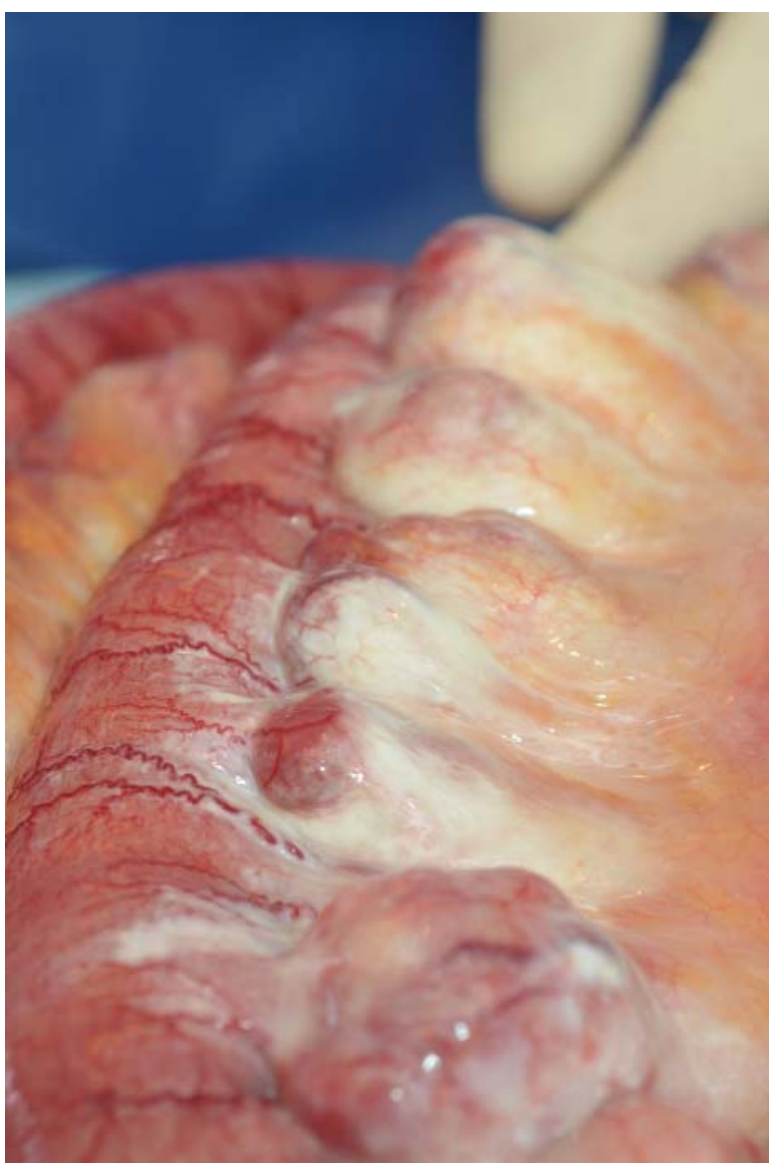

Figure 1 Lymphatic infiltrate in small bowel mesentery. the patient deteriorated during the course of the clerking, becoming more tachycardic and confused.

CT scanning of the abdomen revealed moderate amounts of free fluid and lymphadenopathy in the small bowel mesentery. Due to the patient's rapid deterioration a laparotomy was performed; the abdomen was found to be full of milky fluid; this was confirmed to be chyle on later biochemical analysis. The small bowel had twisted on its mesentery and looked slightly dusky while being covered in bright white lymphatic infiltrate (figure 1).

The volvulus was corrected whereupon the duskiness and white discolouration began to resolve. No further action was required; the patient recovered well and was discharged home 4 days later.

While commoner in children, midgut volvulus causing chylous ascites is rare in adults with only four cases reported in the literature. ${ }^{12}$ This case illustrates how volvulus may occur at any age; it mimics any condition causing peritonitis with free fluid, and is unlikely to be considered as a diagnosis prior to laparotomy. It can cause severe rapid deterioration but is easily correctible with prompt surgery.

\section{Learning points}

- Midgut volvulus can occur in patients of any age and is easily correctible with surgery.

- Chylous ascites is an unusual cause of peritonitis and free fluid, mimicking many other conditions.

- In a rapidly deteriorating patient with peritonitis the patient should have an urgent laparotomy.

Competing interests None.

Patient consent Obtained.

\section{REFERENCES}

1. Murugan K, Spence RA. Chylous peritonitis with small bowel obstruction. Ulster Med J 2008;77:132-3.

2. Kondrat'ev NP. Small intestine volvulus complicated by acute chylous ascites in a pregnant woman. Khirurgiia 1980;(22):90-1. 


\section{BMJ Case Reports}

This pdf has been created automatically from the final edited text and images.

Copyright 2012 BMJ Publishing Group. All rights reserved. For permission to reuse any of this content visit http://group.bmj.com/group/rights-licensing/permissions.

BMJ Case Report Fellows may re-use this article for personal use and teaching without any further permission.

Please cite this article as follows (you will need to access the article online to obtain the date of publication).

Pengelly S, Potiszil K, Feldman M. Spontaneous midgut volvulus causing chylous ascites in an octogenerian. BMJ Case Reports 2012;10.1136/bcr-2012-006950, Published XXX

Become a Fellow of BMJ Case Reports today and you can:

- Submit as many cases as you like

- Enjoy fast sympathetic peer review and rapid publication of accepted articles

- Access all the published articles

- Re-use any of the published material for personal use and teaching without further permission

For information on Institutional Fellowships contact consortiasales@bmjgroup.com

Visit casereports.bmj.com for more articles like this and to become a Fellow 